\title{
A gondozás-neveléstől a nevelés-gondozásig: kisgyermeknevelési koncepciók változásai a szakemberképzésben és a bölcsődei munkában
}

\author{
Nyitrai ÁGNes \\ Kaposvári Egyetem
}

\begin{abstract}
A kora gyermekkor pszichológiai és gazdasági jelentöségének felismerése, a társadalomban, ezen belül hangsúlyozottan a kisgyermekes családok életében és igényeiben zajló változások, továbbá a kora gyermekkori fejlődésre vonatkozó új kutatási eredmények jelentös változásokat generáltak a bölcsődei nevelésben-gondozásban. Egyes alapértékek és a rájuk épülö módszerek változatlanok maradtak, mások a változások következtében alakultak ki vagy alakultak át, keretezödtek újjá, szakmai nézeteken belül egyes hangsúlyok módosultak. Jelen tanulmány célja, hogy hozzásegitse az olvasót a kisgyermeknevelés értelmezéséhez részint a bölcsődepedagógia koncepcionális változásainak, részint a szakemberképzés ezen változásokat indukáló vagy követő fejlődésének bemutatásával.
\end{abstract}

Kulcsszavak: bölcsődepedagógia, gondozás és nevelés kora gyermekkorban, gondozónö- és kisgyermeknevelö képzés

\section{Bevezetés}

A kora gyermekkor pszichológiai és gazdasági felértékelődése és a kisgyermeket nevelő családok bölcsődével szembeni elvárásainak differenciálódása következtében, továbbá a tágabb kontextusú társadalmi változásoknak köszönhetően a 2019-ben 167 éves múltra visszatekintő bölcsődei nevelés jelentős módosulásokon, átalakulásokon ment keresztül az elmúlt évtizedekben. Ezek érintették az ellátás ágazati hovatartozását (az egészségügyből a szociális szférába, ezen belül a gyermekvédelem rendszerébe kerülés), a szakemberképzés ágazatváltásait (egészségügyből a szociális szolgáltatás és a pedagógus képzés területére lépés) és szintnövekedését (a tanfolyami képzésektől a középfokú képzéseken át az érettségire épülő felsőfokú képzések, valamint a BA-szinten folyó képzés megvalósulása), továbbá az ellátórendszer differenciálódását (a hagyományos bölcsődék mellett más ellátási formák és az alapellátásra épülő szolgáltatások megjelenése).

Mindezek a változások folyamatos módosulásokhoz vezettek a kisgyermeknevelés-gondozás szakmai-módszertani kultúrájában is. A szakmai közgondolkodás érzékenyen és sokféleképpen reagál a folyamatokra és azok eredményeire, jelentőségére és hasznosságára vonatkozóan egyaránt („Régen is így csináltuk, semmi új nincs ebben!", "Végre a pedagógia is fontossá vált, nem csak gondozunk.”, „Régen sokkal jobb volt." stb.). Számos megválaszolandó kérdés fogalmazódik meg a bölcsődei nevelés-gondozás szakmai-módszertani kultúrájához kapcsolódóan, ezek hangsúlyozottan érintik a régi és az új szakmai értékek találkozását, egymásra hatását, összekapcsolódásuk lehetőségeit.

Jelen tanulmány célja a szakmai-módszertani kultúra alakulásában zajló folyamatokról történő gondolkodás elősegítése a bölcsődeimódszertani koncepciók és a szakemberképzés változásainak rövid áttekintésével. A bölcsődei ellátás főbb korszakai ${ }^{1}$ :

1. A kezdetektől a II. világháború végéig (1852-1945)

2. A II. világháború végétől a Bölcsődék Országos Módszertani Intézetének (továbbiakban: BOMI) létrejöttéig (1945-1969)

\footnotetext{
${ }^{1}$ A bölcsődei ellátás főbb állomásainak figyelembevételével kialakított saját korszakolás.
} 
3. A BOMI működésének időszaka ${ }^{2}$ (1970-1997)

4. A BOMI átszervezésétől (1998) napjainkig.

Jelen tanulmány elsősorban a 2. és a 3. korszak főbb pedagógiai-módszertani nézeteinek és a szakemberképzés alakulásának bemutatására vállalkozik.

\section{A kezdetektől a II. világháború végéig (1852-1945)}

Az iskoláskor előtti korosztály nevelésére, gondozására szakosodott intézmények, az óvodák és a bölcsődék a 19. század első felében jöttek létre: az első óvodát 1816-ban nyitották Skóciában, az első bölcsődét 1844-ben alapították Párizsban (Vokony, 2002). Az óvoda- és bölcsődelétesítéshez vezető társadalmi folyamatok között meghatározó szerepet játszott a nők tömeges munkába állását eredményező ipari fejlődés, de befolyással bírt a gyermekkor önálló életszakaszként történő kezelése is.

A bölcsődék a kezdetektől fogva három funkcióval rendelkeztek: céljuk volt a dolgozó anyák gyermekeinek napközbeni ellátása, melyhez a szociális-családtámogató funkció kapcsolódott. Az ellátott korosztály fokozott érzékenysége, gondoskodásigénye erős egészségügyi funkciót eredményezett. Mivel a gyermekkel való valamennyi viselkedésünk pedagógia, nevelés (Pikler, 1972 idézi: SzántóFéder, 2017. 14. o.), ezért a pedagógiai funkció folyamatos létezése is nyilvánvaló. Természetesen a bölcsődei ellátás történetének egyes időszakaiban az egyes funkciók súlya és hangsúlyai rendkívül különbözőek voltak.

\footnotetext{
2 A Bölcsődék Országos Módszertani Intézete történetét több átszervezés, más intézményekkel való gazdasági és/ vagy módszertani integráció kísérte, esetenként az intézmény neve is megváltozott átmenetileg (pl. Bölcsődék Módszertani Központja 1990-1992 között). Ugyanakkor a fö feladatok, funkciók: a kutatás, a szakmai-módszertani fejlesztés, a szakemberképzés és továbbképzés, ide értve a képzések fejlesztését és a képzések megvalósításában való részvételt is, az ország valamennyi bölcsődéjének szakmai monitorozása és támogatása, központi módszertani bölcsőde működtetése végig jelen voltak az intézmény működésében.
}

Az 1852-ben Pesten megnyílt első magyar bölcsőde Alapszabályában korszerü egészségügyi és pedagógiai nézetek fogalmazódtak meg, ez utóbbiak közül főleg a szeretetteljes bánásmód szükségességére és a játék jelentőségének felismerésére utalók emelendők ki. A gondozóktól elvárt volt a gyengéd bánásmód, a gyermekeket csak kivételes esetben volt szabad megfeddni. A játékokkal kapcsolatban szigorú biztonsági szempontok fogalmazódtak meg: éles, hegyes, festett tárgyakat nem adtak a kicsik kezébe. A gyermekeket kedvük szerint engedték játszani (Ambrus, 1968).

\section{A II. világháború végétől a BOMI létrejöttéig (1945-1969)}

A második világháborút követően a bölcsődei nevelés erős politikai hangsúlyokat kapott. Kiemelt jelentőségűvé vált a kollektív nevelés, az intézményi nevelésnek meghatározó szerepet szántak a szocialista embereszmény megvalósításában, a gyermek nevelésén túl a szülők nevelésében is. A női egyenjogúság meghatározó kritériuma volt a munkavállalás, így rendkívüli jelentőséget nyert a napközbeni kisgyermekellátás biztosítása állami (tanácsi) és üzemi bölcsődék létesítésével.

A bölcsődék mennyiségi gyarapításán túl hangsúlyossá váltak a szakmai fejlesztésre irányuló törekvések is. Akócsi Sándorné és Varga Ágnes a bölcsődeellenőrzések során szerzett tapasztalataik alapján fogalmaztak meg fontos szakmai észrevételeket és javaslatokat az egészségügyi szakdolgozók folyóiratában, az Egészségügyi Munkában. A bölcsődékben rendkívül nagy hiányosságokat találtak a gyermekekkel való foglalkozás, a gyermekek értelmi, mozgási, érzékszervi megfigyelése és gondozása terén. A csecsemő szellemi fejlődésének elősegítése érdekében a hang, a mozgás, a szín stb. ingerek jelentőségére hívták fel a figyelmet. A mozgásfejlődés feltételeinek biztosítása érdekében javasolták a játszókert kialakítását és a 3 hónaposnál idősebb gyermekek számára a hempergő biztosítását. Általános pedagógiai elvként megfogalmazták, hogy a gyermekekkel derűvel, beszélgetéssel kell foglalkozni. 
A gondozás-neveléstől a nevelés-gondozásig...

Hangsúlyozták a családdal való együttműködés szükségességét és a munkatársak egymással való kapcsolatának jelentőségét is. A bölcsődékben 1955. január 1-jével vezették be az egészségügyi törzslapot; Akócsiné és Varga javaslata szerint ide az orvos bejegyzésein túl a gondozónő is bejegyezheti a gyermek értelmi, érzelmi, érzékszervi és mozgásfejlődésének mozzanatit a saját megfigyelései alapján. A nevelés megtervezésében véleményük szerint segítséget, ötletet adhat az óvodai nevelés. Kiemelték a tisztaság és az otthonosság szerepét is (Akócsiné és Varga, 1955).

Az 1956-ban megjelent központi tartalmi szabályozó dokumentum, A bölcsődék szervezeti és müködési szabályzata igen részletesen tárgyalja a bölcsődék létesítésének és müködtetésének valamennyi aspektusát. A Szabályzatnak A gyermekek egészségügyi gondozása és nevelése c. fejezete fogalmaz meg lényeges szakmai-módszertani elvárásokat a gondozó-nevelő munkával kapcsolatosan. Lényeges szemléleti alapvetésként a dokumentum leszögezi, hogy a gondozást és a nevelést egymástól elválasztani nem lehet. A szakmai szemléletmódot lényegében meghatározó alapelv értelmezése és megvalósulása még sokáig váratott magára. Falk pl. a következőket írja: „A gondozás és nevelés sokat emlegetett egysége azonban még ma is gyakran üres frázis" (Falk, 1981. 49. o.). A kor ideológiai szempontjainak megfelelően a gyermekek nevelése kollektív, de a gondozónő „legyen figyelemmel az egyes gyermekek képességeire, hajlamaira, egyéni tulajdonságaira, egészségi állapotára és testi fejlettségére" ( $A$ bölcsődék szervezeti és müködési szabályzata, 1956. 23. o.). Az egyéni bánásmód megvalósításának alapfeltételeként az életkor szerinti homogén csoportok kialakítását jelölték meg, és központi szerepet szántak a napirendnek, ezen belül a felesleges várakozási idő kiküszöbölésének, a játékra minél több idő biztosításának. A gondozónőtől elvárt volt az otthonosság megteremtése és a jó hangulat biztosítása, a gyermek mozgás- és beszédfejlődésének támogatása. A nagyobb korcsoportokban az ismeretszerzés módszeres kibővítését, irányított és szabad foglalkozások kialakítását írta elő a dokumentum. „A gyermekeket helyes szokások és jó kapcsolatok kialakításával, példamutatással kell nevelni" (A bölcsődék szervezeti és müködési szabályzata, 1956. 24. o.). Fokozott gondoskodást tartottak szükségesnek a fejlődésben elmaradt gyermekek esetében, a bölcsődeorvos és a gyógypedagógus bevonásával. A megfelelő bútorzat biztosítása segíti a nevelés céljainak elérését. A játékoknak és a különböző nevelési eszközöknek egészségügyi és pedagógiai szempontok szerint válogatottnak kell lenniük. A dokumentum az egészségügyi és a pedagógiai elgondolások együttes jelenlétét tükrözi.

Velkey László gyermekorvos és munkatársa, Szemerszky Bálintné a bölcsődének a nevelésben betöltött szerepéről írt a Gyermekgyógyászat c. folyóiratban 1958-ban. Álláspontjuk szerint a tökéletes egészségügyi ellátás mellett a gyermekek szellemi és lelki nevelését is biztosítani kell a bölcsődében. A nevelés alapja a szeretet, ami garantáltan megvéd a hospitalizmustól. A bölcsődei neveléshez szükséges az anyai szeretet természetének pedagógiai és ideggyógyászati elemzése. A bölcsődés gyermeknek megfelelő nyugalomra, elegendő ingerre és a gondozás során kellemes együttműködésre van szüksége. A gondozónőnek a játékban az együttjátszás szintjén is fontos szerepe van, nem elég a gyermek környezetét játékkal telerakni. A gyermeket, a gondozónőt és a szülőket is nevelni kell, mert csak a gyermek, a gondozónő, a bölcsőde és a szülők alkotta négyes minden tagjának együttmüködése biztosítja az optimális feltételeket (Velkey és Szemerszkyné, 1958).

A bölcsődei nevelés egyik kiemelkedő személyisége Akócsi Sándorné ${ }^{3}$, akinek meghatározó szerepe volt az 1960-as évek komplex bölcsődefejlesztési koncepciójának kidolgozásában és megvalósításában. Pedagógusként sokat tett a pedagógiai szemlélet erősítéséért

\footnotetext{
3 1951-től 1973-ig bekövetkezett haláláig volt a Népjóléti/ Egészségügyi Minisztérium bölcsődei területért felelős munkatársa volt. http://www.magyarbolcsodek.hu/ egyesuletunk/dijaink. Letöltés: 2019. augusztus 28.
} 
és a bölcsődei gondozónők képzésének és továbbképzésének fejlesztéséért is. Akócsiné több munkájában is részletezi a gondozónővel kapcsolatos elvárásokat, a hivatás főbb összetevőit (mai szóhasználattal élve a gondozónő szakmai kompetenciáit), hangsúlyozta a bölcsődei nevelőmunka jelentőségét, pedagógiai tevékenységként értelmezve a gondozónői tevékenységet, a gondozást is beleértve (Akócsiné, 1967, 1968). A korosztály érzékenysége miatt a három éven aluli gyermekek intézményes ellátása az egészségügyi ágazathoz tartozik, de a feladatba bevonandó a pedagógus, a pszichológus, a mérnök, a jogász, a közgazdász stb. is. A gondozás és nevelés egysége értelmezésében azt is jelenti, hogy a gyermekkel kapcsolatos valamennyi teendőt a gondozónő látja el, akit alkalmassá kell tenni a gyermekkel való közvetlen érzelmi kapcsolatra és a gyermek korának megfelelő pedagógiai módszerek alkalmazására is (Akócsiné, 1971/1986).

Az 1950-es, 1960-as években a kor ideológiai-politikai irányának megfelelően a nevelés mindenhatóságát hirdették, (nevelésen hangsúlyozottan a felnőtt direkt befolyását értve), és ez természetesen a bölcsődei neveléshez kapcsolódó módszertani elképzeléseken is éreztette hatását. A tervezett foglalkozásoknak nagy szerepet szántak a gyermekek fejlődése, fejlesztése szempontjából. A foglalkozások jellemzői pl. Kabainé tankönyvéből rekonstruálhatók (Kabainé, 1959). A leírások alapján a gondozónőknek napra lebontva előre meg kellett tervezniük, hogy mikor milyen tevékenységgel és tartalommal kívánják a gyermekek értelmi-, beszéd-, mozgás stb. fejlettségét növelni, és minden egyes foglalkozáshoz konkrét célt is meg kellett jelölni. A mindennapok gyakorlatában a foglalkozások az egész csoportnak szóltak, minden gyermeknek a gondozónő irányítása, iránymutatása alapján aktívan részt kellett vennie ezekben, elvárt volt a foglalkozáshoz kapcsolódó feladat megoldása, alkotás létrehozása is. A gyermekkel szembeni elvárások gyakran túlzóak voltak, ezekben az esetekben sokszor a gondozónő oldotta meg a gyermek helyett a feladatot. A foglalkozásokban a hospitalizmus megelőzésének eszközét is látták. A foglalkozások megszervezésére jelentős hatást gyakorolt az óvodai nevelés módszertana.

A foglalkozások merevségének oldását, a személyre szabott gondozónői beavatkozások alkalmazását a tevékenységre serkentéstől várták, melynek kidolgozása Keresztúri Ferencné nevéhez füződik (Leveleki, Keresztúriné, Forrai és Kabainé, 1969; Keresztúriné, 1971/1986). Keresztúriné (1971/1986) abból indul ki, hogy ha a játék a nevelés alapvető eszköze, a nevelés pedig a személyiség céltudatos, tervszerü alakítása, akkor a személyiség csak akkor alakítható, ha a tevékenység irányított, vagyis a gondozónő tudatos játékirányítása nélkülözhetetlen. „Nem a csoport, hanem az egyén játékát kell irányítani, és mindig az egyénhez, a gyermek játékfejlettségéhez kell igazodni" (Keresztúriné, 1971/1986. 43. o.). A tevékenységre serkentés előre meghatározott nevelési program szerint zajlik, lényege a gyermek érdeklődésének felkeltése. Az érdeklődés jeleinek észlelése esetén a gondozónő elkezdi az adott tevékenységet úgy, hogy ezzel tevékenységre serkentse a gyermeket. A tevékenységre serkentésnek mindig valamilyen képességcsoport fejlesztése a célja (beszéd, észlelés, mozgás stb.) képek, mese, vers, mondóka, bábozás, rajzolgatás, gyurmázás, énekelgetés segítségével (Leveleki és mtsai, 1969; Gyöngy, 2014). Az eredeti elképzelések szerint a gyermek ebben önként vett részt, a mindennapok gyakorlatában azonban az önkéntesség gyakran sérült. A módszerhez kapcsolódó számos konkrét ötlet leírásában gyakran tetten érhető, hogy az elsődleges cél a fejlesztés. Egy példa erre: „A képek nézegetése, a mese, a mondóka, a vers elsősorban a beszédfejlesztés célját szolgálja, de érzelmi és esztétikai hatása is jelentős. A kép, a mese, a mondóka, a vers mint a tevékenység serkentése akkor hat valóban ösztönzőleg a gyermekre, ha az anyagot helyesen választjuk ki, jól adjuk elő, és a légköre, a szituáció, amelyben elhangzik - megfelelő" (Leveleki és mtsai, 1969. 142. o.). Manapság pont fordítva gondoljuk ezt: elsődlegesnek tekintjük az érzelmi hatást: csak a gyermeket érzelmileg megérintő mese, vers, mondóka hat a fejlődé- 
A gondozás-neveléstől a nevelés-gondozásig...

sére. A bölcsődei nevelés ezen időszakában a gondozás elsősorban egészségügyi-higiéniai és technikai jellemzőkkel rendelkezett, a gondozási helyzetekben rejlő pedagógiai lehetőségek kevéssé kaptak hangsúlyt, bizonyítéka ennek pl. a párhuzamos gondozás vagy az állandó fürdőszobás gondozónő.

A gondozónőképzés fejlődésének jelentős állomása az 1965-ös tanterv (Stróbl, é. n.), melyet dr. Pikler Emmi, az Országos Csecsemő- és Kisgyermekgondozási Módszertani Intézetének ${ }^{4}$ igazgató föorvosa és munkatársai dolgoztak ki. A gondozónőképzés időtartama két évre emelkedett. A felvételt elvben érettségihez kötötték, ennek azonban nem sikerült érvényt szerezni. A tantervben új tantárgyként jelent meg a pszichológia, a neveléstan óraszáma pedig ötszörösére emelkedett. A tantervben szerepelt a gyermekirodalom, az ének-zene, a manuális gyakorlatok és a háztartási ismeret is. Fő tantárgy volt az egészséges csecsemő fejlődése, gondozása, táplálása. Nagy hangsúly helyeződött az elmélet és a gyakorlat kapcsolatára, a gyakorlóhely állandóságára is (Stróbl, é. n.). Ekkor jelent meg dr. Pikler Emmi szerkesztésében Az egészséges csecsemő és gyermek fejlődése és gondozása c. háromkötetes, több kiadást megért tankönyv ${ }^{5}$, mely a pikleri gondozáspedagógia részletes összefoglalása és hosszú évekig a szakemberképzés egyik alap tankönyve volt (Pikler, 1972).

A bölcsődei nevelés-gondozás módszertani fejlesztésében bekapcsolódtak az óvodai nevelés elismert szakemberei is, pl. Forrai Katalin, Kereszúri Ferencné, Kabainé dr. Huszka Antónia stb. Ez tágabb szakmai-közéleti kontextust eredményezett. 1967-ben alakult meg a Magyar Pedagógiai Társaság Kisgyermeknevelési

\footnotetext{
4 Az Országos Csecsemő- és Kisgyermekgondozási Módszertani Intézet 1970-től 1998-ig: Csecsemőotthonok Országos Módszertani Intézete (CSOMI vagy közismert nevén Lóczy), később Pikler-Intézet, Pikler-Ház.

5 A könyv az 1954-ben megjelent Csecsemőgondozónők és gyermekápolónők tankönyve II. és III. kötetének, ill. az 1961-ben megjelent Az egészséges gyermek fejlődése és gondozása három éves korig c. tankönyvnek átdolgozott, bővített kiadása (Pikler, 1972. 11. o.).
}

Szakosztálya, mely az iskoláskor előtti nevelés művelőit hívta soraiba. 1970-ben a Szakosztály Átmenetek iskolás korig címmel tanulmánykötetet $^{6}$ jelentetett meg az V. Nevelésügyi Kongresszus tiszteletére, melyben Falk Juditnak a kisgyermek megismerésével és a fejlődési naplónak a csecsemőotthoni átmenetek segítésében játszott szerepével foglalkozó tanulmánya is helyet kapott (Falk, 1970).

\section{A BOMI müködésének időszaka (1970-1997)}

1970-ben jött létre a Bölcsődék Országos Módszertani Intézete dr. Polónyi Erzsébet főigazgató főorvos vezetésével, és ez új fejezetet nyitott a bölcsődei szakma fejlődésének történetében ${ }^{7}$. Az Intézet tevékenységkörei: a működő bölcsődék szakmai ellenőrzése, a bölcsődék hálózattá fejlesztése, tudományos kutatások folytatása és azok eredményeire építkezve új módszertani levelek kidolgozása, a szakemberképzés és továbbképzés folyamatos fejlesztése koherens szakmai rendszer kialakulását alapozták meg.

Ugyanebben az évben alakult meg a Csecsemőotthonok Országos Módszertani Intézete (CSOMI) az Országos Csecsemő- és Kisgyermekgondozási Módszertani Intézetből, hasonló profillal dr. Pikler Emmi vezetésével az állami gondoskodásban élő gyermekeket nevelő csecsemőotthonok szakmai fejlesztésére, támogatására. A két intézet szakmai munkája számos ponton összekapcsolódott. A gondozáspedagógiában a BOMI a pikleri elveket követte, a játékpedagógia tekintetében csak az 1979-es Játék a bölcsődében c. módszertani levél (Ferenczy, 1979) hatálya idején egyezett a két intézmény álláspontja, a későbbiekben az ellátott gyermekek élethelyzetéből fakadó

\footnotetext{
6 Szabadi Ilona, Dr. Hegedüs György és Dr. Hermann Alice (1970, szerk.): Átmenetek iskolás korig. Magyar Pedagógiai Társaság, Budapest.

Maga az önálló Intézet az 1997. évi 31. a gyermekek védelméről és a gyámügyi igazgatásról szóló törvény 1998. január 1-jei hatályba lépésével megszűnt, a tevékenységek egy részét az Országos Család- és Gyermekvédelmi Intézet mint jogutód folytatta tovább.
} 
különbözőségek miatt voltak hangsúlyeltolódások a felnőtt játékba való bekapcsolódási lehetőségeit illetően a két intézet között (például Gyöngy, 2014).

A „BOMI-korszak” a bölcsődei szakma fejlődésének egy kiemelkedően dinamikus időszaka. A módszertani bölcsődék hálózatának kiépülésével egységes módszertani támogató- és monitoring rendszer jött létre. A módszertani levelek megfogalmazását és kipróbálását kutatások előzték meg. Nemzetközi kapcsolatok épültek a kutatás és a módszertani fejlesztések területén (elsősorban német és angolszász területen). Szakmai támogató és érdekvédelmi szervezetek alakultak, mint pl. a Bölcsődei Dolgozók Demokratikus Szakszervezete (1989), a Bölcsődei Szakmai Kollégium (1990) és a Magyar Bölcsődék Egyesülete (1995). Az 1980-as évek közepétől fogadták a bölcsődék az atipikus fejlődésű, sajátos nevelési igényű gyermekeket is (meghatározott feltételek megléte esetén). Az 1990-es években megjelentek az alapellátáson túli szolgáltatások és a bölcsőde mellett a családi napközi mint egésznapos ellátást nyújtó szolgáltatás is. Jelen tanulmány hangsúlyozottan a bölcsődepedagógia koncepcionális változásaira és a szakemberképzés fejlődésére fókuszál, a BOMI teljes tevékenykörének részletes elemző bemutatása meghaladja annak kereteit.

$\mathrm{Az}$ 1970-es évek elején a tevékenységre serkentés módszertani elöírásait követték a bölcsődék, melynek visszásságait a szakemberek egyre világosabban látták. A módszer megszüntetésében nagy szerepe volt a BOMI munkatársak CSOMI-ban szerzett tapasztalatainak, mely szerint a gyermekek a felnőtt bármilyen irányítása nélkül is képesek elmélyülten játszani ${ }^{8}$ (Gyöngy, 2014). „A tevékenységre serkentés alapjában véve kötött foglalkozás volt, minden nap meghatározott időben, meghatározott tartalommal, előre meghatározott, de naponta változó témával" (Polónyi, 2000,

\footnotetext{
8 A CSOMI (Csecsemőotthonok Országos Módszertani Intézete) a kezdetektől a pikleri gondozáspedagógiát követte, a tevékenységre serkentést nem alkalmazta.
}

o. n.). Bár a tevékenységre serkentés esetében a módszer egyik, azt a foglalkozásoktól megkülönböztető alapelve volt, hogy a gondozónő kezdeményezései egy-egy gyermeknek szólnak, a mindennapok gyakorlatában azonban nem volt érzékelhető a különbség a kétféle módszertani kultúra között. Sok esetben inkább a gondozónő volt aktív, a gyermekeket nem feltétlenül a kezdeményezés tartalma, hanem sokkal inkább a gondozónő által használt szemléltetőeszközök kötötték le (Polónyi, 2000). A módszer talán egyetlen előnyének tekinthető, hogy az eszközöket meg is kaphatták a gyermekek. A kezdeményezések mélyén komoly teljesítményelvárás húzódott meg, elsősorban az jelentette a kiindulópontot, hogy mit akar a gondozónő megtanítani a gyermekeknek, nem a gyermekek érdeklődésének további megerősítése, ahogy az a módszer leírásából inkább következett volna. Problémát okozott az is, hogy a tevékenységre serkentés után a gyermekeknek nehéz volt visszatérni az elmélyült szabad játékhoz, „vagy teljes tétlenségbe süllyedtek, vagy nagyon aktívvá, sőt, agresszívvé váltak, szaporodtak a konfliktusok" (Polónyi, 2000, o. n.). A másik nehézséget az okozta, hogy a gondozás gyakran elhanyagolódott, mechanikus és gyors volt, a gondozónők egy része másodlagosnak tartotta a sokkal látványosabb tevékenységre serkentéshez képest.

A tevékenységre serkentésnek (és módszertani elődjének, a foglalkozásnak is) az egyik legnagyobb módszertani negatívuma volt a kötelező jelleg. Bár mindkét módszer esetében a kidolgozók a gyermekek számára biztosított önkéntes bekapcsolódási lehetőséget hangsúlyozták, nyilvánvaló, hogy a gyermek számára fontos felnőtt figyelemfelhívó tevékenysége akkor is a gondozónő közelébe vonzotta a gyermeket, ha egyébként önmagától nem választotta volna az adott játékot, tevékenységet.

A tevékenységre serkentést a „szabad” játékot ${ }^{9}$ a középpontba helyező módszertani levél váltotta fel (Ferenczy, 1979), mely a felnőttnek elsősorban feltételmegteremtő szere-

\footnotetext{
9 Az idézőjelet az indokolja, hogy a játék definíciója szerint minden játék szabad.
} 
A gondozás-neveléstől a nevelés-gondozásig...

pet szán a gyermekek játékában, a tényleges bekapcsolódást csak bizonyos helyzetekben tartja elfogadhatónak, akkor is időben és tartalomban is erősen szűkre szabott keretek között. Ferenczy (1979) hangsúlyozza, hogy a jó hangulatú, jó közérzetű gyermek napjának nagy részét önálló játékkal tölti. Fontos kérdés számára, hogy a gyermekek mennyire képesek önállóan, a felnőtt beleszólása nélkül hosszabb ideig játszani, és az intézmény tud-e ehhez megfelelő kereteket biztosítani. A gyermek játékában legmeghatározóbbnak tartja azt, hogy a gyermek mennyire érzi jól magát a bölcsődében. A játékhoz szükséges jó légkör megteremtése a gondozónő feladata, ezen kívül ő biztosítja az elegendő időt, helyet és a jól megválogatott és jól tárolt játéktárgyakat is. A gondozónő folyamatosan figyelemmel kíséri az egész gyermekcsoport és benne minden egyes gyermek tevékenységét, és szükség esetén (pl. olyan konfliktushelyzetben, amelyet a gyermekek nem tudnak megoldani) segítséget nyújt. Ha a gyermekek hívják a játékba, akkor bekapcsolódhat rövid időre, de az a jó, ha háttérben marad és minél előbb kilép a játékból. Ferenczy (1979) kitér arra is, hogy egyes tevékenységek (pl. rajzolás, gyöngyfüzés) a felnőtt közreműködését igénylik, mely csak technikai jellegű segítség legyen.

Az 1979-es Játék a bölcsődében c. módszertani levél a gondozónőnek a játéktevékenységben való látványos visszavonulását, háttérben maradását hirdette, utat engedve ezzel a pikleri gondozáspedagógia hangsúlyozottá válásának. „A csecsemő- és a kisgyermek nevelésének legfontosabb színtere a gondozás. Végre eltűnőben van intézményeinkből az a sokáig uralkodó szemlélet, amely a testi gondozást egyszerű technikai műveletnek tekintve kissé lenézte, $\mathrm{s}$ amely oda vezetett, hogy a gondozónőnek csak a gondozáson kívüli tevékenységét tekintették nevelőmunkának" (Falk, 1981. 49. o.). Falk szerint a gondozásnak a nevelésben való jelentőségét elsősorban a gondozási helyzetek kétszemélyessége, intimitása alapozza meg, fontos ezen túl a gyermek számára a szükségleteinek felismerése, jelezni tudása, amely elősegíti a megfelelő szükségletkielégítést, ami viszont a tárgyak felé fordulásnak az alapját képezi (Falk, 1981). Tardos a gondozónő gondozás közbeni magatartását részletesen elemezve a mozdulatokra, a hívásra, a kínálásra, a kérésre, a gondozónő beszédének és válaszkészségének fontosságára hívja fel a figyelmet (Tardos, 1980, 1981).

Az 1979-es Játék a bölcsődében c. módszertani levél elméleti megalapozottságát tekintve is óriási előrelépés volt a foglalkozások és a tevékenységre serkentés világához képest. Míg az előző két módszertani elképzelés hangsúlyozottan a felnőtt nevelési céljainak oldaláról közelített a játékhoz, a módszertani levél a játék elméleti értelmezéséből kiindulva jut el a módszertani megoldásokhoz. Amennyire kidolgozott volt a feltételek megteremtésének kérdésköre, annyira nehezen megragadható és merev volt a gondozónőnek a gyermekek játékába való bekapcsolódási lehetőségeinek korlátozása. A bölcsődei nevelés-gondozás mindennapjaiban gyakran tapasztalható volt az, hogy a gondozónők akkor sem kapcsolódtak be, amikor ez fontos lett volna, és arra is hasonlóan bőven volt példa, hogy a módszertani előírásokat mondhatni figyelmen kívül hagyva a gyermek igényeihez igazodóan, de számukra is örömet adóan játszottak a gyermekekkel. A szűkös keretek tágítását tűzte ki célul a Játék a bölcsödében c. új módszertani levél (Korintus, Nyitrai és Rózsa, 1997), amely a felnőttnek a gyermek játékában való részvételét a játék örömet adó funkciójának az erősítése és a gyermek igényeihez igazodás oldaláról közelítve szabályozta. A módszertani levél konkrét részvételi formák mentén (pl. kezdeményezés, ötletadás, együttjátszás, viselkedési szabályok tisztázása stb.) részletezi a módszertanilag támogatható és helyteleníthető bekapcsolódási módokat, hangsúlyozva, hogy a felnőtt csak a gyermek igényeihez igazodva kapcsolódhat be a játéktevékenységbe, ellenkező esetben, a játék felnőtt általi irányításának következtében a tevékenység már nem tekinthető igazán játéknak.

A rendszerváltást követő években vált igazán kézzelfoghatóvá a bölcsődei szakmai módszertani kultúra elvi alapjainak értelmezése és rendszerbe foglalása: a teljes bölcsődei ellátást szabályozó tartalmi dokumentumok 
születtek ${ }^{10}$. A Bölcsődei szakmai és szervezési útmutató (Mátay, 1993) önálló fejezetben tárgyalja a bölcsődei gondozás-nevelés kérdéseit, megfogalmazva az alapelveket, feladatokat, feltételeket, módszereket és eszközöket, kitérve a bölcsődei nevelés főbb helyzeteire, a gondozásra és a játékra is. 1997-es átdolgozott változatának egyik fejezete $A$ bölcsődei gondozás-nevelés szakmai alapprogramja, mely első az alapprogramok sorában (Mátay, 1997). Az 1993-as dokumentumhoz képest a szakmai alapprogram kitér a sérült gyermekek gondozásával, fejlesztésével kapcsolatos elvi alapokra is, definiálja az alapellátásra épülő szolgáltatásokat, és elméletileg megalapozza azok működését (Mátay, 1997). A dokumentum a gondozás és nevelés egységének elvét a két fogalom logikai értelmezésével világítja meg: „A nevelés és a gondozás elválaszthatatlan egységet alkotnak. A nevelés tágabb, a gondozás szűkebb fogalom: a gondozás minden helyzetében nevelés is folyik, a nevelés helyzetei, lehetőségei azonban nem korlátozódnak a gondozási helyzetekre" (Mátay, 1997. 9. o.). A fenti megközelítés egyenrangúvá, azonos hangsúllyal rendelkezővé teszi a két területet, implicit módon kimondja a rangsorolásoktól való tartózkodást.

A pedagógiai gondolkodásnak fontos aspektusává vált a szülőkkel való partneri együttműködés kialakítása.

Az 1970-től 1998-ig terjedő időszak a szakemberképzés fejlődésének is jelentős időszaka volt. A kutatás-szakmai-módszertani fejlesztés-képzés egysége valósult meg azáltal, hogy a BOMI és a CSOMI szakemberei részt vettek a képzésfejlesztésben (a tantervi fejlesztésekben, a tananyag-kidolgozásban és az oktatásban egyaránt). Mind a képzések, mind a továbbképzések központi tantervek alapján szerveződtek. A szakmai újdonságok lényegében azonnal megjelentek a szakemberképzésben- és továbbképzésben, melynek

\footnotetext{
10 Az első volt a sorban a Bölcsődei szakmai és szervezési útmutató dr. Mátay Katalin igazgató föorvos szerkesztésében, Bölcsődék Országos Módszertani Intézete, Budapest. 1993
}

rendszere folyamatosan differenciálódott (Nyitrai, 2016). 1975-től az egészségügyi szakközépiskolákban már nem lehetett az érettségivel együtt csecsemő- és gyermekgondozó végzettséget szerezni, így a rendszerváltásig lényegében megszűnt a nappali tagozatos képzés. A pályafutásukat szakképzetlenül kezdő gondozónők munka mellett iskolai végzettségüktől függően egy vagy két év alatt szerezhettek szakképesítést.

A képzés és továbbképzés fejlődési folyamatában egyre növekedett a pedagógiai-pszichológiai témák aránya is. 1975-ben jelent meg Tardos Anna háromkötetes Neveléstan c. munkája (Tardos, 1975), mely a pikleri pedagógiai elvek mentén a bölcsődei és a csecsemőotthoni nevelés feladatait, módszereit és a gondozónő tevékenységét, feladatait részletezte.

1978-ban került kidolgozásra és bevezetésre a másodfokú szakosító, az ún. szakgondozónő képzés tanterve ${ }^{11}$, mely a bölcsődei szakma legrangosabb képzése volt az ezredfordulóig. A képzésre csak azok jelentkezhettek, akik érettségizettek és szakképzettek voltak, legalább 2 éves szakmai gyakorlattal rendelkeztek, még nem töltötték be a 45. életévüket, és vezetői, vezető helyettesi beosztásban dolgoztak, vagy azok várományosai voltak. A jelentkezők felvételi vizsgán vettek részt. A képzés szakdolgozattal, gyakorlati, írásbeli és szóbeli képesítő vizsgával zárult.

1985-ben új tanterv ${ }^{12}$ és hozzá kapcsolódóan új tananyag ${ }^{13}$ került kidolgozásra.

Az 1990-es évek elején került kidolgozásra világbanki támogatással az érettségire épülő ún. 4+3 éves képzés ${ }^{14,}$ melynek első éve a gyermekápolókkal közös képzés volt, a máso-

11 Tanterv a bölcsődei szakgondozók másodfokú szakositó képzéséhez. Egészségügyi Szakdolgozók Központi Továbbképző Intézete, Budapest, 1978

12 Tanterv. Csecsemö- és gyermekgondozói szakositó képzés. Egészségügyi Minisztérium Gyógyító Ellátási Főosztály, Budapest. 1985

13 Dr. Polónyi Erzsébet (1985, szerk): Tananyag a csecsemőés gyermekgondozói szakositó tanfolyam hallgatói részére. I-II. Egészségügyi Minisztérium, Budapest.

${ }^{14}$ Az első változat egy érettségire épülő kétéves képzés volt, mely végül nem került bevezetésre: a tanterv kidolgozása 
A gondozás-neveléstől a nevelés-gondozásig...

dik évtől lehetett szakosodni a gyermekápolói vagy a gyermekgondozói területre. Az 1995ben kidolgozott Országos Képzési Jegyzékbe az érettségire épülő 3 éves képzés és a szakgondozó képzés került be.

\section{A BOMI átszervezésétől (1998) napjainkig}

A bölcsődei ellátás fejlődésének 1998-tól napjainkig tartó időszakának egyik fő jellemzője a bölcsődepedagógia újraértelmezése. A kora gyermekkori nevelés iránti érdeklődés nemzetközi viszonylatban felerősödött a kora gyermekkor pszichológiai és gazdasági jelentőségének felismerésének köszönhetően. A nemzetközi kutatási eredményekhez való jobb hozzáférésnek, továbbá az EUhoz csatlakozással is összefüggésbe hozható kutatási és fejlesztési együttműködéseknek köszönhetően új fogalmak épülnek be a bölcsődepedagógia fogalomrendszerébe, régi fogalmak kereteződnek át a megváltozott szociokulturális kontextusnak is köszönhetően, pl. kompetencia alapú szemléletmód a nevelésben, a felnőttnek a gyermek fejlődésének támogatásában játszott szerepe, a gyermeki kompetenciák fejlődésének feltételeiről való gondolkodás stb. A kisgyermeknevelőtől elvárt a korábbi időszakokhoz képest nagyobb tudatosság, a nevelésről, saját tevékenységéről egyfajta perspektívában gondolkodás képessége (pl. a nevelés tervezése), ezek viszont nem jelentik a gyermek tevékenységének direktebb irányítását (Nyitrai, 2015).

A szakemberképzés fejlődésének kiemelkedő időszaka ez a periódus: az érettségire épülő 5.4-es szintű OKJ-s szakképesítések mellett, azok megtartásával 1999-ben a gondozóképzés akkreditált felsőfokú szakképzésként bekerült a felsőoktatásba, ezen belül a pedagógusképzésbe. A 2008. októberi MABhatározat a BA-szak létesítésének engedélyezéséről a bölcsődei szakma nagy álmát váltotta valóra. A felsőoktatáshoz kapcsolódó

és kipróbálása után közvetlenül adódott a lehetőség a hároméves képzés kidolgozására. szakemberképzés fejlődésének jelen szakaszát mutatja be a következő táblázat:

\begin{tabular}{|l|l|}
\hline Év & A gondozónő/kisgyermeknevelő képzés fejlödésének új állomása \\
\hline $1998-1999$ & $\begin{array}{l}\text { A felsőfokú szakképzés (OKJ 5.5) programjának kidolgozása, } \\
\text { MAB-akkreditáció (Budapesti Tanítóképzỏ Főiskola és BOMI/ } \\
\text { OCSGYVI) }\end{array}$ \\
\hline 2005 & $\begin{array}{l}\text { A felsőfokú szakképzés (OKJ 5.5) központi programjának } \\
\text { kidolgozása }\end{array}$ \\
\hline 2008 & $\begin{array}{l}\text { A felsőfokú szakképzés új, moduláris és kompetencia alapú képzési } \\
\text { programjának kidolgozása (szociális szolgáltatás szakmacsoport, } \\
\text { átjárhatóság a képzéseken belül, elágazások) }\end{array}$ \\
\hline $2008-2009$ & Csecsemő- és kisgyermeknevelö BA szak alapítása és indítása \\
\hline 2012 & $\begin{array}{l}\text { A felsőfokú szakképzés (OKJ 5.5) megszünése, helyette: felsőoktatási } \\
\text { szakképzés (FOSZK) programjának kidolgozása }\end{array}$ \\
\hline 2015 & Felsőoktatási szakképzés (FOSZK) megszűnése \\
\hline 2017 & $\begin{array}{l}\text { Tanulási eredmény alapú képzési és kimeneti követelmények } \\
\text { Új mintatantervek, új képzési programok }\end{array}$ \\
\hline
\end{tabular}

1. táblázat. A felsőoktatás keretében szervezett gondozónő/kisgyermeknevelő képzés fejlődése 1998 és 2019 között

A tágabb neveléstudományi kontextusba ágyazottság, a nagyobb elméleti megalapozottság és tudatosság természetszerűleg kedvez(het) a pedagógiai személetmód korszerűsödésének, fejlődésének. Ebben pozitív befolyása lehet a továbblépési lehetőségeknek (szakirányú továbbképzések, neveléstudományi mesterszak, doktori képzés) is. Ugyanakkor a felsőoktatásnak új a bölcsődei terület, a bölcsődei ellátásnak pedig új a pedagógusképzés jelenléte. A harmónia kialakításában nagy befolyással bír a szerepelképzelések és szerepelvárások összehangolása, a kompetenciahatárok együttes megrajzolása.

\section{Záró gondolatok}

A kezdetektől jelen lévő pedagógiai szemléletmód a bölcsődei ellátás egyes korszakaiban nagyon különböző területi prioritásokat követett. A hatvanas-hetvenes évek koncepciózus képességfejlesztést célzó nevelésmódszertani kultúráját a hetvenes évek végétől a gondozáspedagógia váltotta fel, mely a képességfejlődés elősegítését illetően a felnőttnek hangsúlyozottan feltételmegteremtő szerepet szánt, a fejlődésben a gyermeki öntevékenységet tekintette meghatározónak. A kilencve- 
nes években került sor a bölcsődepedagógia átkeretezésére, mely elsősorban a felnőttnek a gyermek játéktevékenységében való részvételéhez kapcsolódó módszertani kultúra terén hozott újat.

A kisgyermeknevelés az utóbbi években divattémává is vált, sokan sokféle megközelítésben, sokféle álláspontról indulva vonódnak be a szakmai-módszertani kultúra alakításába. Ennek a jelenségnek kétségkívül pozitív, elismerésre méltó fejlődést generáló hatásával együtt tapasztalható a párhuzamos valóságok megjelenése, egymás mellett létezése, valamint olyan elképzelések megfogalmazódása is, melyek nehezen találnak rá a rendszerbe illeszkedés útjára. Ebben segítségül szolgálhat a bölcsődei szakterület történetének, a szakmai-módszertani kultúra főbb állomásainak megismerése.

\section{Felhasznált irodalom}

A bölcsődék szervezeti és müködési szabályzata (1956): Egészségügyi Minisztérium, Budapest.

Akócsi Sándorné (1967): Nevelés a bölcsődében. Egészségügyi Felvilágositás, o. n.

Akócsi Sándorné (1968): A bölcsődék fejlődése, helyzete. Népegészségügy, 49. 5. sz., 283-286.

Akócsi Sándorné (1971/1986): Bölcsődék szervezésének időszerü kérdései. Előadás. Elhangzott az I. Országos Bölcsődei Ankéton Szolnokon, 1971-ben. In: I. Országos Bölcsődei Ankét, Szolnok, 1971. Szolnok, 1986. 5-14.

Akócsi Sándorné és Varga, Á.: (1955): Hogyan javíthatjuk bölcsődei munkánkat? Egészségügyi Munka, 5. sz., 75-78.

Ambrus Erzsébet (1968): Az első magyar bölcsőde és orvosai. Orvosi Hetilap, 109. 40. sz., 2211-2213.

Gyöngy Kinga (2014): A bölcsődei müvészeti nevelés elözményei és jelen gyakorlata. ELTE Eötvös Kiadó, Budapest.

Falk Judit (1970): A kisgyermek megismerése és az átmenetek biztosítása a csecsemőotthoni fejlődési napló segítségével. In: Szabadi Ilona, Hegedüs György és Hernann Alice (szerk.): Átmenetek iskoláskorig. Magyar Pedagógiai Társaság, Budapest, 7-23.

Falk Judit (1981): A gyermek gondozásával kapcsolatos feladatok. In: Tardos, A. (szerk.)
Jegyzet a bölcsödei és csecsemöotthoni gondozónők részére. Kéziratként. Egészségügyi Szakdolgozók Központi Továbbképző Intézete, Budapest, 49-60.

Ferenczy Ágnes (1979): Játéktevékenység a bölcsődében. 2. sz. módszertani levél. In: Elöadások - Közlemények - Dokumentumok. Módszertani levelek, irányelvek. Bölcsődék Országos Módszertani Intézete, Budapest, é.n.

Kabai Zné (1959): Neveléstan. Egészségügyi Szakiskolák Jegyzete. Medicina Könyvkiadó, Budapest.

Keresztúri Ferencné (1971/1986): Játékfeltételek a bölcsődében. Előadás. Elhangzott az I. Országos Bölcsődei Ankéton Szolnokon, 1971-ben. In: I. Országos Bölcsődei Ankét, Szolnok, 1971. Szolnok, 1986, 33-39.

Korintus Mihályné, Nyitrai Ágnes és Rózsa Judit (1997): Játék a bölcsődében. Módszertani levél. Bölcsődék Országos Módszertani Intézete, Budapest.

Leveleki Eszter, Keresztúri Ferencné, Forrai Katalin és Kabainé Huszka Antónia (1969): A nevelés eszközei a bölcsődében és a csecsemőotthonban. In: Kabainé Huszka Antónia (1969, szerk.): A gondozónö, védőnő és gyermekápolónö nevelési feladatai. Gyermeknevelés IV., V., VI. Budapest, 141-175.

Mátay Katalin (1993, szerk.): Bölcsődei szakmai és szervezési útmutató. Bölcsődék Országos Módszertani Intézete, Budapest.

Mátay Katalin (1997, szerk.): A bölcsődék müködési engedélyének szakmai követelményei. Bölcsődék Országos Módszertani Intézete, Budapest.

Nyitrai Ágnes (2015): Pedagógiai szemléletmód a bölcsődei nevelésben, gondozásban. In: Podráczky Judit (szerk.) Szemelvények a kisgyermeknevelés köréből I. Kaposvári Egyetem, Kaposvár, 35-56.

Nyitrai Ágnes (2016): A gondozónőképzéstől a kisgyermeknevelő képzésig. Mozaikok a bölcsődei szakemberképzés történetének 1970 és 2009 közötti időszakáról. In: Bölcsődevezetők Kézikönyve. Vezetési, gazdasági és szakmai ismeretek. 8. kieg. kötet: 2016. augusztus. Raabe Klett Kiadó, Budapest, 2-31.

Pikler Emmi (1972, szerk.): Az egészséges csecsemő és gyermek fejlődése és gondozása 1-2-3. Egészségügyi szakiskolák tankönyve. Medicina Könyvkiadó, Budapest. 
A gondozás-neveléstől a nevelés-gondozásig...

Polónyi Erzsébet (1985, szerk.): Tananyag a csecsemó- és gyermekgondozói szakositó tanfolyam hallgatói részére. I-II. Egészségügyi Minisztérium, Budapest.

Polónyi Erzsébet (2000): Kapcsolatom a bölcsődékkel. II. rész. BOMINFO Hírcsomag, 2000/1. 58. Hírlevél

Stróbl Mária (é. n.): A bölcsődék útja a szakképzés tükrében. Kézirat. Nemzeti Család- és Szociálpolitikai Intézet, Budapest.

Szabadi Ilona, Dr. Hegedüs György és Dr. Hermann Alice (1970, szerk.): Átmenetek iskoláskorig. Magyar Pedagógiai Társaság, Budapest.

Szántó-Féder Ágnes (2017): Aktív gyerek, gondolkodó felnőtt. Syllabux Könyvkiadó, Budapest.

Tanterv a bölcsödei szakgondozók másodfokú szakositó képzéséhez (1978): Egészségügyi Szakdolgozók Központi Továbbképző Intézete, Budapest.

Tanterv. Csecsemö- és gyermekgondozói szak szakositó képzés (1985): Egészségügyi Minisztérium Gyógyító Ellátási Főosztály, Budapest.
Tardos Anna (1980): A gondozónő keze. Elöadások - Közlemények - Dokumentumok XXIV. CSOMI. Kézirat, 13-22.

Tardos Anna (1975): Neveléstan. I-II-III. Csecsemő és gyermekgondozónő, gyermekápolónőképző egészségügyi szakiskolák hallgatói részére. Egészségügyi Minisztérium Középfokú Oktatási Osztálya, Budapest.

Tardos Anna (1981): A nevelőmunka néhány kérdése. . In: Tardos Anna (szerk.) Jegyzet a bölcsödei és csecsemöotthoni gondozónök részére. Kéziratként. Egészségügyi Szakdolgozók Központi Továbbképző Intézete, Budapest, 61-89.

Velkey László és Szemerszky Bálintné (1958): A bölcsőde szerepe a nevelésben. Gyermekgyógyászat, 1-3. 25-34.

Vokony Éva (2002): Kis magyar bölcsődetörténet. Kapocs, 1. 2. sz., 50-54.

\section{Internetes forrás}

Bölcsődék Egyesülete http://www.magyarbolcsodek. hu/egyesuletunk/dijaink. [2019. augusztus 28.]

\section{From care and education to education and care: changes in concept of early childhood educator's training and of nursery education}

Recognition of the psychological and economical importance of early childhood, changes in society, first of all in the life and needs of families with young children and results of studies in early childhood development and education have been leading to important changes in nursery education and care. Some basic values and methods have stayed alive, some have changed in different ways, and some new values and methods emerged. Understanding the changes is very important for early childhood educators and for other specialists. The aim of this study is to help them by the interpretation of the conceptual changes in nursery education and care and by the presentation of changes in training-programs for early childhood educators.

Keywords: nursery education, early childhood education and care, training for early childhood educators 